\title{
PROCEEDINGS OF THE
} PREHISTORIC SOCIETY

\begin{tabular}{ll}
\hline \hline VOLUME 50 & 1984 \\
\hline \hline
\end{tabular}

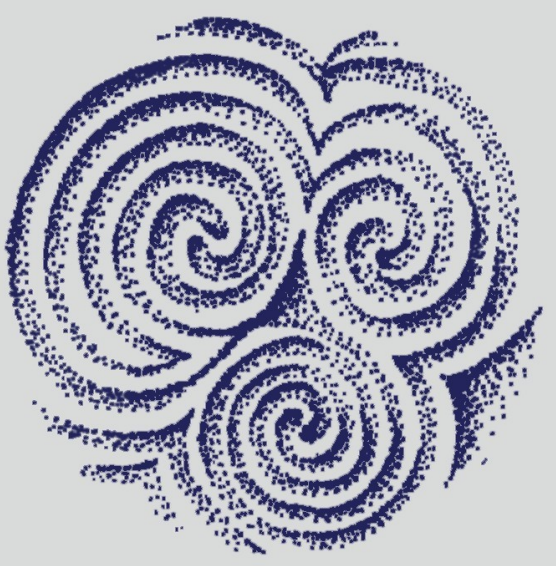




\section{THE PREHISTORIC SOCIETY}

THE SOCIETY promotes interest in prehistoric archaeology, encourages and engages in research, and disseminates knowledge of prehistory. The Society holds monthly meetings in London from October to March, and meetings in Durham. A Spring conference is held in London, field excursions and study tours take place in Britain and on the continent, and a summer conference is held at a regional centre in Britain or abroad. The Proceedings are published annually.

MEMBERSHIP. All applications for membership, subscriptions and changes of address should be sent to the Prehistoric Society, The Museum Bookshop, 36 Great Russell Street, London wGIB 3PP, England. Subscriptions are due, without reminder, on I January.

SUBSCRIPTION RATES:

$\begin{array}{ll}\text { Individual } & \mathfrak{E}_{10} \\ \text { Institutional } & \mathfrak{E}_{20} \\ \text { Joint } & £_{3} \text { (second member of the same household) }\end{array}$

PRoceedrngs. All matters concerning the Proceedings should be sent to the Hon. Editor, The Prehistoric Society, Department of Archaeology, University of Southampton, Southampton sog $5 \mathrm{NH}$, England.

Contributions to the Proceedings should be sent to the Editor. All contributors are encouraged to consult the Editor at an early stage in the preparation of papers, and to obtain from him the detailed instructions to contributors.

Books for review and periodicals for exchange should be sent to the Editor.

Back numbers and index volumes are generally available; see inside back cover for details.

Copyright in the Proceedings rests with the Society.

RESEARCH FUND. During 1984 the Society made the following awards from its research fund: M. Bound (excavation of the Giglio Etruscan wreck); C. Gingell and A. Lawson (excavation of the first millennium bc site at Potterne); C. Malone and S. Stoddart (Gubbio survey and excavation project); P. Turnbull (excavations at Stanwick); S. Green (excavations at the upper palaeolithic site of Little Hoyle); R. Bradley (completion of excavation and research on Cranborne Chase).

The Society hopes to make one or more awards from its research fund in 1986 . Applications will be considered from members carrying out research into prehistoric archaeology in any part of the world. Application forms are obtainable from the Hon. Secretary, The Prehistoric Society, Department of Archaeology, The University, Southampton sog 5 $\mathrm{NH}$, England. The closing date for applications for 1986 is I January 1986.

R. M. Baguley AWard. The R. M. Baguley Award for 1984 was presented to Mr A. M. Fleming for his paper, 'The prehistoric landscape of Dartmoor, Part 2: North and East Dartmoor', in Volume 49 of the Proceedings. 


\title{
PROCEEDINGS OF THE PREHISTORIC SOCIETY
}

\section{VOLUME 50}

DECEMBER 1984

\author{
EDITED BY \\ T. C. CHAMPION, M.A., D.Phil., F.S.A. \\ Department of Archaeology, University of Southampton \\ ASSISTED BY \\ JOHN G. EVANS, B.Sc., Ph.D., F.S.A. \\ Department of Archaeology, University College, Cardiff
}

THE PREHISTORIG SOCIETY 
COUNGIL OF THE PREHISTORIG SOCIETY 1984

President

Vice-Presidents

Hon. Secretary

Hon. Treasurer

Assistant Treasurer

Hon. Editor

Assistant Editor

Hon. Meetings Secretary

Local Secretary for the North

Council

Hon. Auditor
G. J. WainWRight, B.A., PH.D., F.S.A.

L. Alcock, M.A., F.S.A.

K. BRanigan, M.A., PH.D., F.S.A.

B. W. Gunliffe, M.A., PH.D., D.LITT., F.B.A., F.S.A.

G. JOBEY, D.S.O., M.A., F.S.A.

C. S. Gamble, M.A., PH.D., F.S.A.

D. Thomson, M.A.

Mrs M. Langdon, B.A.

T. C. Champion, M.A., D.PhiL., F.S.A.

J. G. Evans, B.SG., PH.D., F.S.A.

H. A. W. BURI, M.A., PH.D., F.S.A.

A. F. Harding, M.A., PH.D., F.S.A.

G. W. W. BARKER, M.A., PH.D., F.S.A.

M. G. BELL, B.SC., PH.D., F.S.A.

D. V. ClaAkKe, B.A., PH.D., F.S.A.

G. Guilbert, B.A.

C. Haselgrove, m.A.

J. D. Hedges, B.SC., F.S.A.

N. Johnson, B.SC., M.A.

S. Needham, B.A., PH.D.

D. W. Phillipson, M.A., PH.D., F.S.A.

A. G. Sherratt, M.A., Ph.D., F.S.A.

J. R. Turner

R. D. Whitehouse, M.A., PH.D.

R. GARROD, M.A., PH.D.
PRINTED IN GREAT BRITAIN

BY W. S. MANEY AND SON LIMITED

HUDSON ROAD LEEDS LS9 7 DL 


\section{CONTENTS}

I The pressure of the past: Presidential Address. By G.J. Wainwright

Page I

2 Palaeolithic archaeology in the Mongolian People's Republic: a report on the state of the art. By Myra Shackley

3 The acheulean in Asia? A review of Research on Korean palaeolithic culture. By William S. Ayres and Song NaI Rhee

4 The Japanese palaeolithic: a review. By T. E. G. Reynolds and G. L. Barnes

5 Early palaeolithic in Moravia, Czechoslovakia. By Karel Valoch

6 Far'ah II: a middle palacolithic open-air site in the Northern Negev, Israel. By IsaAc Gilead and Caroline Grigson

7 The ecology of neolithic farming systems as exemplified by the Avebury region of Wiltshire. By R. W. SMITH

8 Intensive survey of prehistoric sites in the Stilo region, Calabria. By Ian Hodder and Caroline Malone

and microfiche inside back cover

9 The excavation of a neolithic cairn at Street House, Loftus, Cleveland. By B. E. VyNER

I 5 I

io Stone circles and megalithic mathematics. By John Barnatt and Gordon Moir

I I The nature of the source and the manufacture of Scottish battle-axes and axe-hammers. By M. B. FENTON

I2 A Bronze Age glass bead from Wilsford, Wiltshire: Barrow $\mathrm{G}_{42}$ in the Lake group. By MARGARET Guido, Julian Henderson, Michael Cable, Justine Bayley and Leo Biek

I 3 The excavation of eighteen round barrows near Shrewton, Wiltshire. By the late Charles GreEN and Stephen Rollo-Smith

I 4 Structured round cairns in West Gentral Wales. By D. K. LeIghton

I5 An early Iron Age farmstead: Site $Q$ of the Assendelver Polders project. By L. L. Therkorn, R. W. Brandt, J. P. Pals and M. Taylor

Notes

Copper mining at Mount Gabriel, Co. Cork: Bronze Age bonanza or post-famine fiasco? A reply. By JOHN S. JAckson

Multistage strategy for sampling settlement sites: an example from Poland. $B y$ W. BRzEZINSKI, M. Dulinicz, Z. Kobylinski, B. Lichy and A. Moszczynski

Moving and erecting the menhirs. By A. Tном

A barbed point from Porth-y-waen, Llanyblodwel, Shropshire. By William Britnelt

A Middle Bronze Age looped palstave from Ollerton, Childs Ercall, Shropshire. By BruCE BenNison

Reviews

Terra Amata and the middle Pleistocene archaeological record of southern France. By PAOLA VILLA 


\section{CONTENTS}

Ancient France, 6000-200o BC: neolithic societies and their landscapes. Edited by Christopher SCARre

Influences méridionales dans l'Est et le Centre-est de la France au Néolithique: le rôle du Massif Central. Edited by J.-P. Daugas

La nécropole de Chenon (Charente). Etude d'un ensemble dolménique charentais. By EDMOND GaUron and Jean Massaud

Inventaire des mégalithes de la France: 7.I, Aveyron. By Jean Clottes and Claude Maurand

Inventaire des mégalithes de la France: 8, Puy-de-Dôme. By Sylvia Amblard

Excavations at Knowth 1: smaller passage tombs, neolithic occupation and Beaker activity. By GEORGE EOGAN

Newgrange, County Meath, Ireland: the late neolithic/Beaker period settlement. By M. J. O'KeLly, Rose M. Cileary and Caragh Lehane, edited by Claire O'Kelly

Demircihüyük I: Architektur, Stratigraphie und Befunde. By Manfred Korfmann

The earliest wheeled transport: from the Atlantic coast to the Caspian sea. By STUART PiggotT

Ranking, resource and exchange: aspects of the archaeology of early European society. Edited by CoLIN Renfrew and Stephen Shennan

The dirks and rapiers of Great Britain and Ireland. By C. B. Burgess and S. GerlofF

The axes of Scotland and Northern England. By P. K. SCHMIdT and C. B. Burgess

Bronzezeitliche Trensen in Mittel- und Osteuropa. By H.-G. HüтreL

Jung-und spätbronzezeitliche Gussformen im nördlichen Schwarzmeergebiet. By V. S. BočKAREv and A. M. LESKOV

Hoards of the Irish Later Bronze Age. By George Eogan

A catalogue of Irish Iron Age antiquities. By BARRY RAFTERY

Cross-channel trade between Gaul and Britain in the pre-Roman Iron Age. Edited by S. MACREADY and F. H. Thомpson

Papers in Iberian prehistory. Edited by T. F. C. BLAGG, R. F. J. Jones and S.J. KeAY

Journal of Irish Archaeology

Beginnings of agriculture. By G. R. Sharma, V. D. Misra, D. Mandal, B. B. Misa and Jagannath PAL

Social and economic organisation in the prehispanic Andes. Edited by D. L. Browman, R. L. Burger and M. A. RiverA 